\title{
DIVISION OF LABOR IN A NEST OF THE SLAVE- MAKING ANT FORMICA WHEELERI CREIGHTON
}

\author{
By EdWARD O. WILsoN
}

Biological Laboratories, Harvard University

It is a well known fact that most of the dulotic Formica are not "host-specific." They normally employ several species as slaves and are apparently governed in their choice at least in part by the species that happen fortuitously to be accessible to the colony. $F$. subintegra Emery, for instance, most commonly enslaves $F$. fusca Linn., but I have seen it associated in cabinet series with $F$. lasioides Emery, $F$. neogagates Emery, and F. schaufussi Mayr, while Creighton (1950) records it in addition with $F$. montana Emery and $F$. pallidefulva Mayr. According to Forel (1928, p. 12), the slave workers may retain some of the behavioral traits peculiar to their species. He notes that in Europe Formica pratensis Retzius workers reared from pupae by $F$. sanguinea Latreille tend to construct the form of nest characteristic of their own species. Talbot and Kennedy (1940) have made observations suggestive of the same behavior in $F$. fusca enslaved by $F$. subintegra. When sanguinea workers kept in observation nests were induced by Forel (op. cit., p. 126) to rear pupae of Polyergus rufescens (Latreille) and several common Formica so that all these species coexisted in the same nest, differences in behavior were noted: "the $F$. exsecta and fusca were distinguished by their activity in working, the Polyergus by their complete idleness, the sanguinea by their skill, and the pratensis by their clumsiness."

During a recent field trip through the western United States, I was able to study in some detail a remarkable compound colony of the slave-maker $F$. wheeleri Creighton ${ }^{2}$ and two slave species ( $F$. neorufibarbis and $F$. fusca) in which behavioral differences were so strong as to produce

${ }^{1} \mathrm{~A}$ tentative determination, since the status of this species relative to $F$. subintegra is still uncertain; see the preceding article by Wilson and Brown. 
a clearcut interspecific division of labor. The complex organization of this colony was so interesting in every detail that I have considered it worthwhile to record below all of my observations, despite the fact that they pertain to a single and possibly aberrant case.

The mixed colony was first encountered at $2: 30$ on a warm, sunny afternoon, July 20, 1952, in a meadow near Madison Junction, Yellowstone Park, Wyoming (elevation 6800 feet). The wheeleri workers, accompanied by large numbers of neorufibarbis and a very few fusca, were in the process of raiding two nests simultaneously, one of fusca about eighteen feet from the home nest, and another of lasioides about seven feet beyond in a straight line. The exteriors of both raided nests were inconspicuous, each consisting of nothing more than several entrance holes in the open ground. The wheeleri-neorufibarbis raiding file contained workers spaced at intervals averaging about six to eight feet. Most were halting at the fusca nest, but some were bypassing it and proceeding on to the smaller lasioides nest. The scene around the raided nests was one of outstanding confusion. Frenzied fusca and lasioides, some carrying brood, were mingled with the wheeleri and neorufibarbis slaves. Running over the same spot were fusca and neorufibarbis from alien nests, possibly drawn to the scene by the general excitement. Needless to say it was difficult at any given time to pick out the slaves, the ants being raided, and the extraneous marauders.

Many of the homeward bound wheeleri were transporting pupae, neorufibarbis slaves, and other wheeleri. The neorufibarbis were never laden and seemed to be running back and forth without contributing any service to the raid. On a single occasion a fusca slave was observed carrying one of its wheeleri mistresses. The method of adult transport was the same as that already described in the literature for other Formica: the ant to be carried was approached face-to-face, seized by the mandibles, and lifted aloft; it submissively curled its body under the head of its transporter, folded in its legs, and became completely still. 
After observing the raid for about an hour, I excavated the fusca nest in part. My efforts were clumsy, and I succeeded only in turning up a few workers and blocking the main entrance galleries. But at this point the role of the neorufibarbis was revealed, for as soon as I buried the access to the nest, they joined in with the wheeleri workers to dig it out again. There was no hesitation in this act, despite the fact that they did not follow through to join in the actual pillaging.

The raid continued through the remainder of the afternoon, the intensity of activity fluctuating as from time to time the number of workers issuing from the home nest rose and then fell again. After 4:00 the raid against the lasioides began to slacken, and by $5: 15$ it had ceased altogether. By 5:30 activity around the fusca nest was also noticeably less.

When the raid had fallen into an obvious decline, around $5: 30$, I proceeded to excavate the wheeleri home nest. The exterior consisted of a low, oblong earthern mound about two-and-a-half feet in maximum length and three inches high. Sparse tufts of grass emerged through the periphery, at one end sheltering three inconspicuous entrance holes. By digging a pit four feet deep in from the side, I uncovered the deepest galleries of the nest at about threeand-a-half feet. Inside the nest the wheeleri were outnumbered by their slaves by at least three to two, while the neorufibarbis and fusca occurred in approximately equal numbers. No lasioides were encountered, despite the fact that the wheeleri had been engaged in a raid against a nest of this species earlier in the day. The upper galleries and chambers of the nest contained large numbers of wheeleri and neorufibarbis and a few small individuals of fusca. The former two species sallied out aggressively to defend the nest. The deeper galleries, those at a depth of about two feet or more, were larger in size and packed with large fusca workers, wheeleri brood, callow wheeleri queens (a single fully colored male was also found), and a small number of wheeleri and neorufibarbis workers. The fusca workers were relatively docile, and nearly all were in a semi-replete condition. Their preponderance 
over other adults in this part of the nest and their close association with the brood gave the strong impression that they were serving as nurses.

At noon on the next day the wrecked nest was visited again. The colony was busily engaged in migrating to the undamaged part of the fusca nest which had been raided the day before. The fusca workers were no longer in evidence and presumably had been forced out. The wheeleri were doing all the work in this operation; most of the workers in the migrating file were carrying something in their mandibles, either brood, or slaves, or other wheeleri. In contrast, many of the slaves were running back and forth with the slave-makers but none were burdened.

In summary, an interspecific division of labor was pronounced in this particular case. The slave-maker species wheeleri functioned in raiding, nest defense, and transport during colony migration. Workers of the slave species neorufibarbis accompanied the wheeleri on their raid and helped them excavate one of the besieged nests when the entrance holes were blocked; they were also active in nest defense. The fusca workers were very passive, did not contribute materially to the slave-raid, and gave every sign of serving primarily as nurses and food receptacles. A deeper significance of the dulotic habit is underscored here. It is apparent that the slave-maker colony not only adds to its labor force quantitatively by taking slaves but may also incorporate specialists that increase the efficiency of the colony in a fashion analogous to that seen in normal worker polymorphism.

Creighton, W. S.

\section{Literature Cited}

1950. The ants of North America. Bull. Mus. Comp. Zool. Harv., 104: $1-585,57 \mathrm{pls}$.

Forel, A.

1929. The social world of ants. English translation by C. K. Ogden. Albert and Charles Boni, New York. Two volumes.

Talbot, M. and C. Kennedy.

1940. The slave-making ant, Formica sanguinea subintegra Emery, its raids, nuptial flights and nest structure. Ann. Ent. Soc. Amer., 33: $560-577$. 

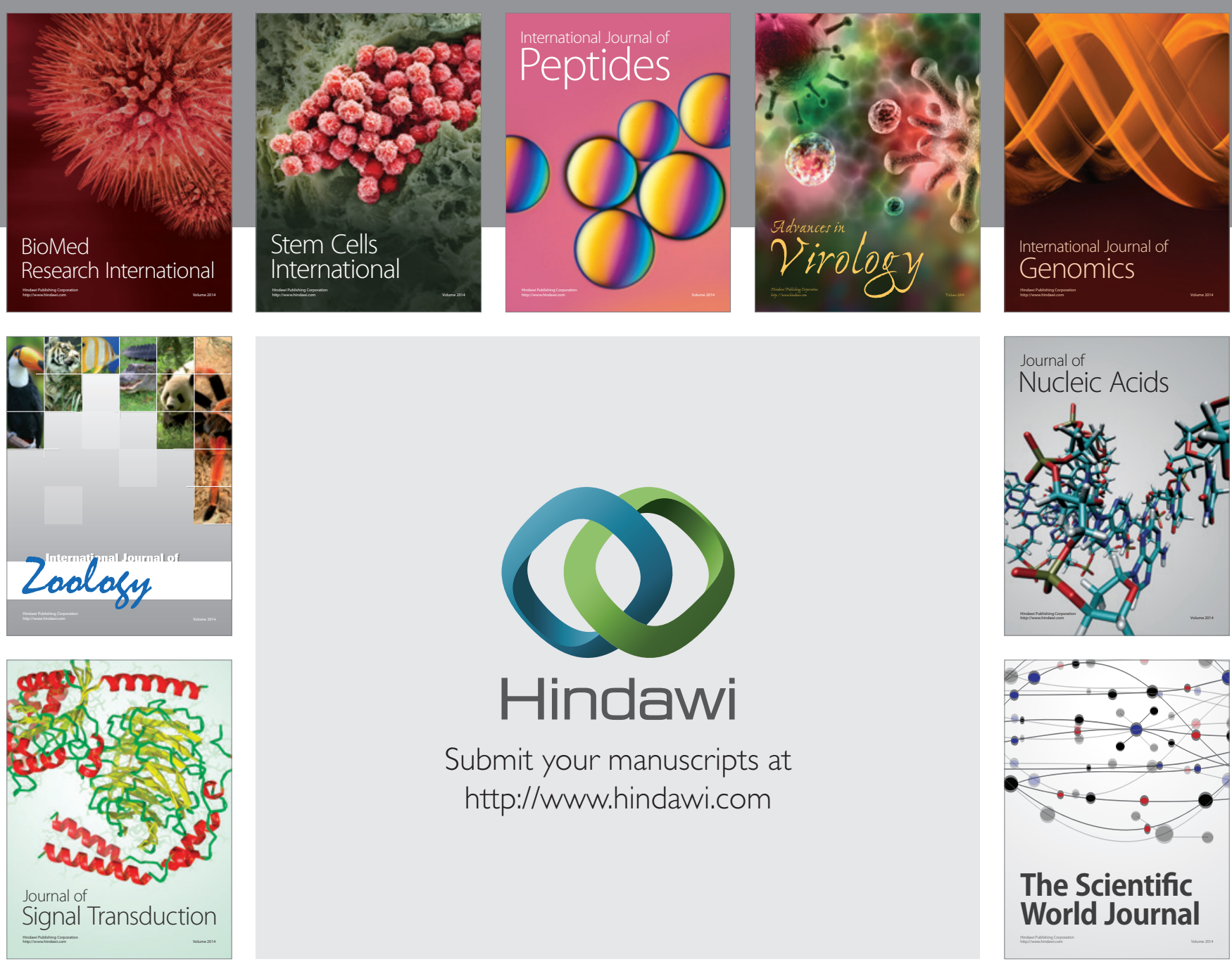

Submit your manuscripts at

http://www.hindawi.com
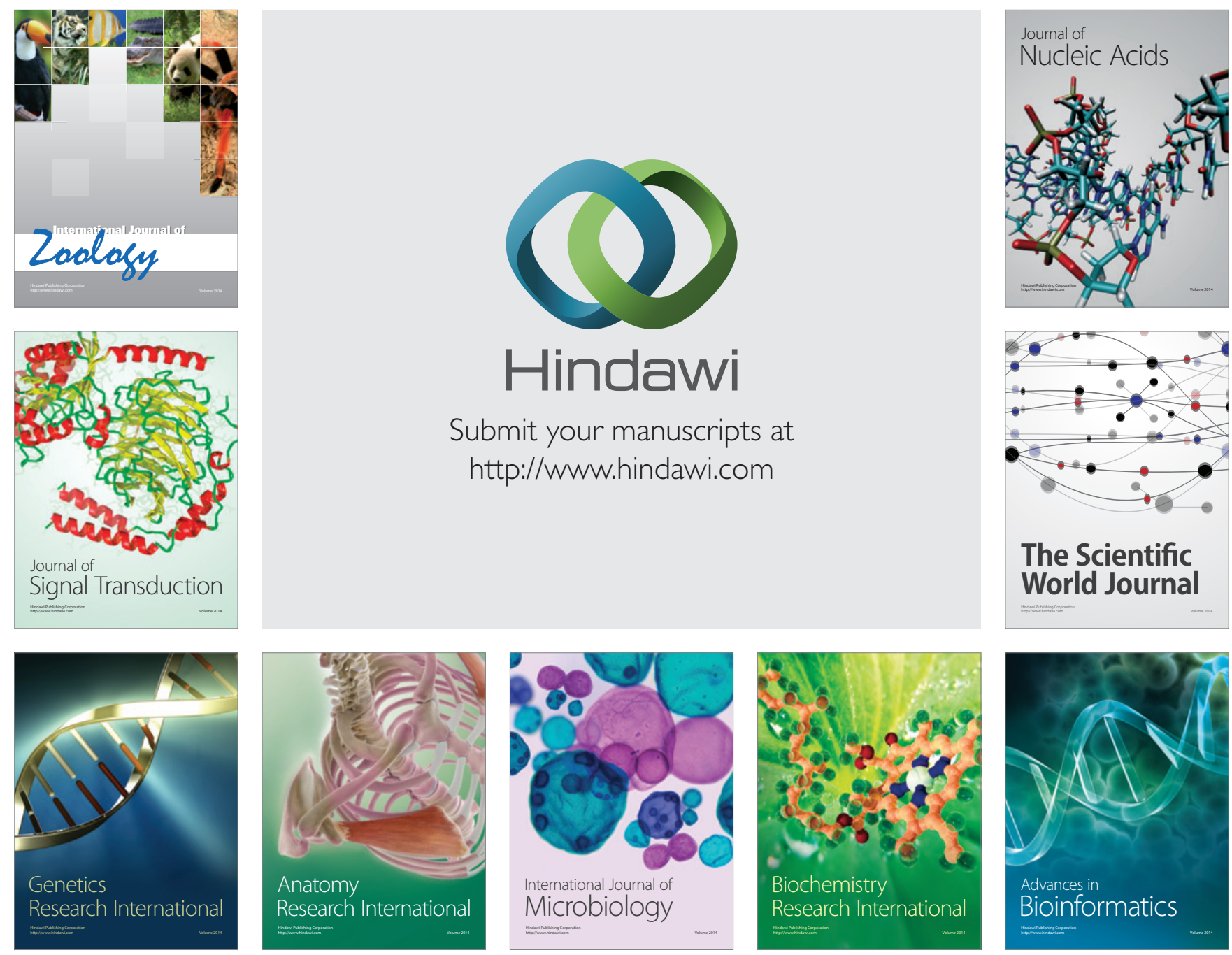

The Scientific World Journal
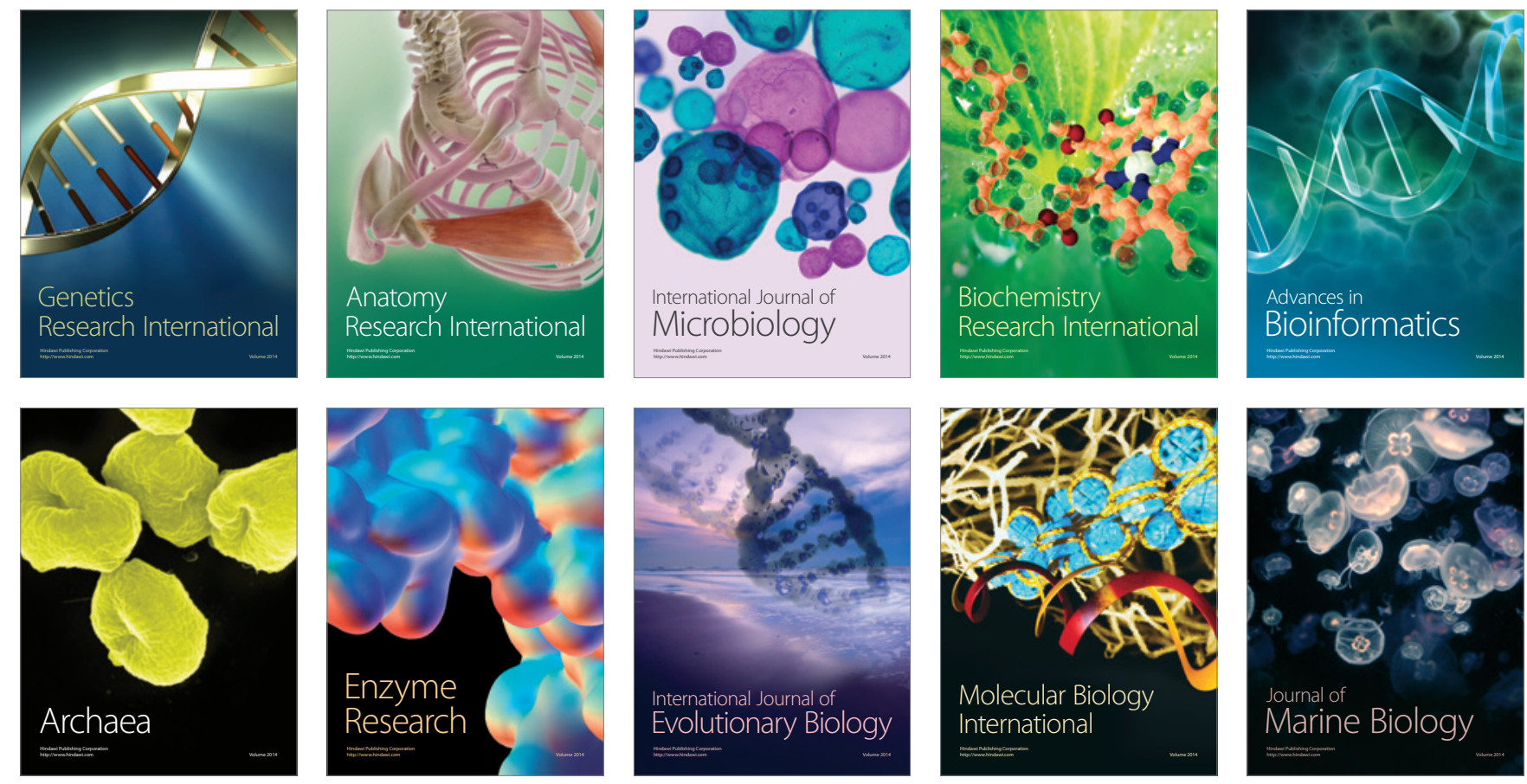